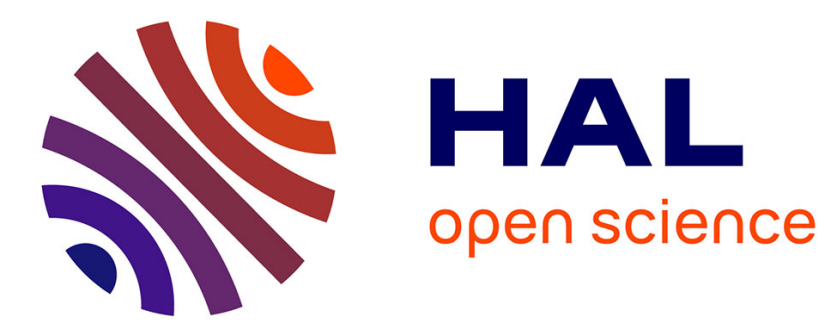

\title{
Identification of 5-lipoxygenase and microsomal prostaglandin E synthase-1 as functional targets of the anti-inflammatory and anti-carcinogenic garcinol
}

Andreas Koeberle, Hinnak Northoff, Oliver Werz

\section{- To cite this version:}

Andreas Koeberle, Hinnak Northoff, Oliver Werz. Identification of 5-lipoxygenase and microsomal prostaglandin E synthase-1 as functional targets of the anti-inflammatory and anti-carcinogenic garcinol. Biochemical Pharmacology, 2009, 77 (9), pp.1513. 10.1016/j.bcp.2009.02.005 . hal-00493492

\section{HAL Id: hal-00493492 \\ https://hal.science/hal-00493492}

Submitted on 19 Jun 2010

HAL is a multi-disciplinary open access archive for the deposit and dissemination of scientific research documents, whether they are published or not. The documents may come from teaching and research institutions in France or abroad, or from public or private research centers.
L'archive ouverte pluridisciplinaire HAL, est destinée au dépôt et à la diffusion de documents scientifiques de niveau recherche, publiés ou non, émanant des établissements d'enseignement et de recherche français ou étrangers, des laboratoires publics ou privés. 


\section{Accepted Manuscript}

Title: Identification of 5-lipoxygenase and microsomal prostaglandin $E_{2}$ synthase-1 as functional targets of the anti-inflammatory and anti-carcinogenic garcinol

Authors: Andreas Koeberle, Hinnak Northoff, Oliver Werz

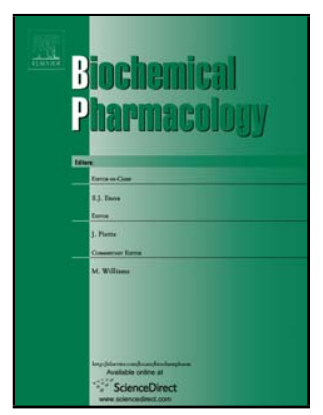

PII:

S0006-2952(09)00105-1

DOI: doi:10.1016/j.bcp.2009.02.005

Reference: BCP 10084

To appear in: $\quad B C P$

Received date: $\quad 9-12-2008$

Revised date: 27-1-2009

Accepted date: 11-2-2009

Please cite this article as: Koeberle A, Northoff H, Werz O, Identification of 5lipoxygenase and microsomal prostaglandin $\mathrm{E}_{2}$ synthase-1 as functional targets of the anti-inflammatory and anti-carcinogenic garcinol, Biochemical Pharmacology (2008), doi:10.1016/j.bcp.2009.02.005

This is a PDF file of an unedited manuscript that has been accepted for publication. As a service to our customers we are providing this early version of the manuscript. The manuscript will undergo copyediting, typesetting, and review of the resulting proof before it is published in its final form. Please note that during the production process errors may be discovered which could affect the content, and all legal disclaimers that apply to the journal pertain. 
Identification of 5-lipoxygenase and microsomal prostaglandin $E_{2}$ synthase-1 as

\section{functional targets of the anti-inflammatory and anti-carcinogenic garcinol}

Running title: Garcinol inhibits 5-lipoxygenase and mPGES-1

Andreas Koeberle $^{\mathrm{a}}$, Hinnak Northoff ${ }^{\mathrm{b}}$, and Oliver Werz ${ }^{\mathrm{c}^{*}}$

a Department for Pharmaceutical Analytics, Pharmaceutical Institute, University of Tuebingen, Auf der Morgenstelle 8, D-72076 Tuebingen, Germany

${ }^{\mathrm{b}}$ Institute for Clinical and Experimental Transfusion Medicine, University Medical Center Tuebingen, Hoppe-Seyler-Straße 3, 72076 Tuebingen, Germany

* Corresponding author: Dr. Oliver Werz, Department for Pharmaceutical Analytics, Pharmaceutical Institute, University of Tuebingen, Auf der Morgenstelle 8, D-72076 Tuebingen, Germany. Phone: +4970712978793; Fax: +497071294565; e-mail: oliver.werz@uni-tuebingen.de 


\begin{abstract}
Garcinol (camboginol) from the fruit rind of Guttiferae species shows anti-carcinogenic and anti-inflammatory properties, but the underlying molecular mechanisms are unclear. Here we show that garcinol potently interferes with 5-lipoxygenase (EC 7.13.11.34) and microsomal prostaglandin $(\mathrm{PG}) \mathrm{E}_{2}$ synthase (mPGES)-1 (EC 5.3.99.3), enzymes that play pivotal roles in inflammation and tumorigenesis. In cell-free assays, garcinol inhibited the activity of purified 5-lipoxygenase and blocked the mPGES-1-mediated conversion of $\mathrm{PGH}_{2}$ to $\mathrm{PGE}_{2}$ with $\mathrm{IC}_{50}$ values of 0.1 and $0.3 \mu \mathrm{M}$, respectively. Garcinol suppressed 5-lipoxygenase product formation also in intact human neutrophils and reduced $\mathrm{PGE}_{2}$ formation in interleukin-1 $\beta$ stimulated A549 human lung carcinoma cells as well as in human whole blood stimulated by lipopolysaccharide. Moreover, garcinol interfered with isolated cyclooxygenase (COX)-1 (EC 1.14.99.1, $\left.\mathrm{IC}_{50}=12 \mu \mathrm{M}\right)$ and with the formation of COX-1-derived 12(S)-hydroxy-5-cis8,10-trans-heptadecatrienoic acid and thromboxane $\mathrm{B}_{2}$ in human platelets. In contrast, neither $\mathrm{Ca}^{2+}$-ionophore (A23187)-induced arachidonic acid release in neutrophils nor COX-2 activity in A549 cells or whole blood, measured as formation of 6-keto $\mathrm{PGF}_{1 \alpha}$, or isolated human recombinant COX-2 were significantly affected by garcinol $(\leq 30 \mu \mathrm{M})$. Together, the high potency of garcinol to selectively suppress $\mathrm{PGE}_{2}$ synthesis and 5-lipoxygenase product formation provides a molecular basis for the anti-inflammatory and anti-carcinogenic effects of garcinol and rationalizes its therapeutic use.
\end{abstract}


Abbreviations used: AA, arachidonic acid; COX, cyclooxygenase; cPL, cytosolic phospholipase; ERK, extracellular signal-regulated kinase; FLAP, 5-lipoxygenase-activating protein; 12-HHT, 12(S)-hydroxy-5-cis-8,10-trans-heptadecatrienoic acid; iNOS, inducible nitric oxide synthase; 5-LO, 5-lipoxygenase; LT, leukotriene; mPGES, microsomal prostaglandin $\mathrm{E}_{2}$ synthase; NSAIDs, non steroidal anti-inflammatory drugs; PG, prostaglandin. 


\section{Introduction}

Garcinol (Fig. 1A) is a polyprenylated acylphloroglucinole contained in the rind of Guttiferae (Garcinia indica, G. huillkensis and G. cambogia), named Kokum, which is used as culinary spice and garnish for curry. In India, Kokum is used in ayurvedic medicine for the treatment of inflammatory and infectious diseases [1]. In rats, garcinol protects against 4-nitroquinoline1-oxide-induced tongue carcinogenesis [2] and azoxymethane-induced colon carcinogenesis [3]. Functional investigations have revealed anti-oxidative [4], anti-proliferative [5], proapoptotic [6], anti-invasive [7], and anti-inflammatory properties of garcinol [6, 8, 9]. Garcinol reduced the expression or activation of kinases involved in cell proliferation (i.e., focal adhesion kinase, extracellular signal-regulated kinase (ERK)-1/2, p38 mitogen-activated protein kinase $[8,10])$, blocked the expression of enzymes involved in the development and progression of cancer and inflammation (i.e., cyclooxygenase (COX)-2 (EC 1.14.99.1) and inducible nitric oxide synthase (iNOS)), and suppressed nuclear factor (NF)אB signalling [8, 10]). However, molecular targets of garcinol are less defined, and thus far, only histone acetyltransferase p300 $\left(\mathrm{IC}_{50}=7 \mu \mathrm{M}\right)$ [11], P300/CBP-associated factor $\left(\mathrm{IC}_{50}=5 \mu \mathrm{M}\right)[11]$, and acetylcholine esterase [12] $\left(\mathrm{IC}_{50}=0.7 \mu \mathrm{M}\right)$ were identified.

Certain COX-1/2-derived prostanoids and 5-lipoxygenase (5-LO)-derived leukotrienes (LTs) initiate and maintain inflammatory and allergic reactions (for review see [13]), and pharmacological intervention with their biosynthesis (i.e., utilizing COX- and 5-LO (EC 7.13.11.34) inhibitors) is applied in therapy of respective diseases. COX-2 and/or 5-LO are also overexpressed in various cancer cells (e.g., prostate, breast, lung, and colon) [14-16], and pre-clinical studies indicate tumor-preventive effects of COX inhibition by non steroidal antiinflammatory drugs (NSAIDs) [17]. Moreover, pharmacological suppression of the 5-LO pathway, using 5-LO inhibitors or inhibitors of the 5-LO-activating protein (FLAP), causes 
apoptosis of various tumor cells $[16,18]$. Prostaglandin $(\mathrm{PG}) \mathrm{E}_{2}$ is the most prominent $\mathrm{COX}$ product in inflammation and tumorigenesis and is formed from $\mathrm{PGH}_{2}$ by $\mathrm{PGE}_{2}$ synthases. The microsomal $\mathrm{PGE}_{2}$ synthase (mPGES)-1 (EC 5.3.99.3) is an inducible isoform functionally coupled to COX-2. Accumulating evidence suggests that mPGES-1 is responsible for massive $\mathrm{PGE}_{2}$ formation associated with pathologies [19]. Therefore, mPGES-1 may represent an alternative drug target for treatment of inflammation and cancer, which is supported by data from mPGES-1 deficient mice and animal studies with selective mPGES-1 inhibitors [19-21].

Despite the anti-inflammatory and anti-tumorigenic potential of garcinol, its effects on the formation of eicosanoids were rarely analyzed. Hong et al. recently showed that garcinol modulates arachidonic acid (AA) metabolism in lipopolysaccharide-stimulated macrophages by blocking cytosolic phospholipase (cPL)A $\mathrm{A}_{2}$ (EC 3.1.1.4) activation due to inhibition of ERK1/2-mediated phosphorylation [10]. However, modulation of PG and/or LT biosynthesis by garcinol or effects on the catalytic activity of the key enzymes involved (e.g., COX-1/2, PG synthases, 5-LO) have not been addressed yet. Here, we demonstrate that garcinol inhibits prostanoid and LT formation in cellular and cell-free assays by preferential and potent interference with mPGES-1 and 5-LO. 


\section{Materials and Methods}

\subsection{Reagents}

Garcinol (Biomol, Hamburg, Germany) was dissolved in dimethyl sulfoxide (DMSO) and kept in the dark at $-20{ }^{\circ} \mathrm{C}$, and freezing/thawing cycles were kept to a minimum. The thromboxane synthase inhibitor CV4151 [22] and anti-6-keto PGF $_{1 \alpha}$ antibody were generous gifts by Dr. S. Laufer (University of Tuebingen, Germany) and Dr. T. Dingermann (University of Frankfurt, Germany), respectively. Materials used: DMEM/High Glucose (4.5 g/l) medium, penicillin, streptomycin, trypsin/EDTA solution, PAA (Coelbe, Germany); $\mathrm{PGH}_{2}$, Larodan (Malmö, Sweden); 11ß-PGE $2, \mathrm{PGB}_{1}, \mathrm{MK}-886$ (3-[1-(4-chlorobenzyl)-3-tbutyl-thio-5-isopropylindol-2-yl]-2,2-dimethylpropanoic acid), 6-keto $\mathrm{PGF}_{1 \alpha}$, human recombinant COX-2, ovine COX-1, Cayman Chemical (Ann Arbor, MI); [5, 6, 8, 9, 11, 12 , 14, $\left.15-{ }^{3} \mathrm{H}\right]$ arachidonic acid $\left(\left[{ }^{3} \mathrm{H}\right] \mathrm{AA}\right)$, BioTrend Chemicals GmbH (Cologne, Germany); Ultima Gold $^{\mathrm{TM}}$ XR, Perkin Elmer (Boston, MA). All other chemicals were obtained from Sigma-Aldrich (Deisenhofen, Germany) unless stated otherwise.

\subsection{Cells and cell viability assay}

A549 cells were cultured in DMEM/High glucose $(4.5 \mathrm{~g} / \mathrm{l})$ medium supplemented with heatinactivated fetal calf serum $(10 \%, \mathrm{v} / \mathrm{v})$, penicillin $(100 \mathrm{U} / \mathrm{ml})$, and streptomycin $(100 \mu \mathrm{g} / \mathrm{ml})$ at $37{ }^{\circ} \mathrm{C}$ in a $5 \% \mathrm{CO}_{2}$ incubator. After 3 days, confluent cells were detached using $1 \times$ trypsin/EDTA solution and reseeded at $2 \times 10^{6}$ cells in $20 \mathrm{ml}$ medium in $175 \mathrm{~cm}^{2}$ flasks. Cell viability was assessed by trypan blue staining and light microscopy. A549 cells $\left(4 \times 10^{5}\right)$ were plated in a $75 \mathrm{~cm}^{3}$ cell culture flask and incubated at $37{ }^{\circ} \mathrm{C}$ and $5 \% \mathrm{CO}_{2}$ for $72 \mathrm{~h}$. Then, garcinol was added and the incubation was continued for 5 or $24 \mathrm{~h}$ before cell viability was 
determined. Treatment with garcinol $(10$ or $30 \mu \mathrm{M})$ for $5 \mathrm{~h}$ did not significantly reduced cell viability, excluding acute cytotoxic effects in the cellular assays used in this study. However, prolonged incubation (24 h) with 10 or $30 \mu \mathrm{M}$ garcinol led to a strong increase in the ratio of dead cells to total number of cells ( $50 \%$ and $71 \%$ dead cells, respectively).

Blood cells were freshly isolated from leukocyte concentrates obtained at the Blood Center of the University Hospital Tuebingen (Germany) as described [23]. In brief, venous blood was taken from healthy adult donors that did not take any medication for at least 7 days, and leukocyte concentrates were prepared by centrifugation $\left(4000 \times \mathrm{g}, 20 \mathrm{~min}, 20^{\circ} \mathrm{C}\right)$. Cells were immediately isolated by dextran sedimentation and centrifugation on Nycoprep cushions (PAA, Coelbe, Germany). Platelet-rich-plasma was obtained from the supernatants, mixed with phosphate-buffered saline (PBS) pH $5.9(3: 2 \mathrm{v} / \mathrm{v})$, centrifuged $(2100 \times \mathrm{g}, 15 \mathrm{~min}$, room temperature), and the pelleted platelets were resuspended in $\mathrm{PBS} \mathrm{pH} 5.9 / 0.9 \% \mathrm{NaCl}(1: 1$, $\mathrm{v} / \mathrm{v})$. Washed platelets were finally resuspended in $\mathrm{PBS} \mathrm{pH} 7.4$ and $1 \mathrm{mM} \mathrm{CaCl} 2$. Neutrophils were immediately isolated from the pellet after centrifugation on Nycoprep cushions, and hypotonic lysis of erythrocytes was performed as described [24]. Cells were finally resuspended in PBS pH 7.4 (PBS) containing $1 \mathrm{mg} / \mathrm{ml}$ glucose and $1 \mathrm{mM} \mathrm{CaCl}_{2}$ (PGC buffer) (purity $>$ 96-97\%).

\subsection{Release of arachidonic acid in neutrophils}

Freshly isolated human neutrophils $\left(3 \times 10^{7} / \mathrm{ml}\right.$ PGC buffer) were pre-incubated with the test compounds for $10 \mathrm{~min}$ prior to stimulation with $\mathrm{Ca}^{2+}{ }^{2}$-ionophore $\mathrm{A} 23187(2.5 \mu \mathrm{M})$. After 5 $\min$ at $37^{\circ} \mathrm{C}$, the reaction was stopped by addition of $1 \mathrm{ml}$ of methanol. After adjusting $\mathrm{pH} 3$ and addition of magarinic acid (11.1 nmol) as internal standard, released AA was separated by solid phase extraction (RP-18 material and elution with methanol) and coupled to 2,4- 
dimethoxyaniline hydrochloride $(0.14 \quad \mathrm{mg}, \quad 0.75 \mu \mathrm{mol})$ using $N$-Ethyl- $N$ '-(3dimethylaminopropyl)carbodiimide $(1.46 \mathrm{mg}, 9.4 \mu \mathrm{mol})$ as coupling reagent for $1 \mathrm{~h}$ at $37^{\circ} \mathrm{C}$. Derivatized AA was analyzed by RP-HPLC (gradient: $71 \%$ methanol / $29 \%$ water to $100 \%$ methanol in $20 \mathrm{~min}$, detection at $272 \mathrm{~nm}$ ).

\subsection{Determination of COX-1 product formation in washed platelets}

Freshly isolated platelets $\left(10^{8} / \mathrm{ml}\right.$ PBS containing $\left.1 \mathrm{mM} \mathrm{CaCl}_{2}\right)$ were pre-incubated with the indicated agents for $5 \mathrm{~min}$ at room temperature. After addition of $5 \mu \mathrm{M}$ AA and further incubation for $5 \mathrm{~min}$ at $37{ }^{\circ} \mathrm{C}$, the $\mathrm{COX}$-1-derived $\mathrm{TxB}_{2}$ was quantified using a $\mathrm{TxB}_{2}$ High Sensitivity EIA Kit (Assay Designs, Ann Arbor, MI). 12(S)-Hydroxy-5-cis-8,10-transheptadecatrienoic acid (12-HHT, non-enzymatically formed from $\mathrm{PGH}_{2}$ ) was extracted and analyzed by HPLC as described [23].

\subsection{Determination of $\mathrm{PGE}_{2}$ and 6-keto $\mathrm{PGF}_{1 \alpha}$ formation in intact $\mathrm{A549}$ cells}

Cellular $\mathrm{PGE}_{2}$ and 6-keto $\mathrm{PGF}_{1 \alpha}$ formation was determined according to [25]. A549 cells $(2 \times$ $10^{6}$ cells) were incubated for $16 \mathrm{~h}$ at $37{ }^{\circ} \mathrm{C}$ and $5 \% \mathrm{CO}_{2}$, the medium was changed, and the cells were stimulated with interleukin-1 $\beta(1 \mathrm{ng} / \mathrm{ml})$ for $48 \mathrm{~h}$. After trypsination, cells were washed with PBS twice. For determination of $\mathrm{PGE}_{2}, 4 \times 10^{6}$ cells per ml PBS containing $\mathrm{CaCl}_{2}(1 \mathrm{mM})$ were pre-incubated with the indicated compounds at $37{ }^{\circ} \mathrm{C}$ for $10 \mathrm{~min}$, and $\mathrm{PGE}_{2}$ formation was started by addition of ionophore A23187 $(2.5 \mu \mathrm{M})$, AA $(1 \mu \mathrm{M})$, and $\left[{ }^{3} \mathrm{H}\right] \mathrm{AA}(18.4 \mathrm{kBq})$. The reaction was stopped after $15 \mathrm{~min}$ at $37{ }^{\circ} \mathrm{C}$, and the samples were put on ice. After centrifugation $\left(800 \times \mathrm{g}, 5 \mathrm{~min}, 4{ }^{\circ} \mathrm{C}\right)$, the supernatant was acidified $(\mathrm{pH} 3)$ by addition of citric acid $(20 \mu \mathrm{l}, 2 \mathrm{M})$, and the internal standard $11 \beta-\mathrm{PGE}_{2}(2 \mathrm{nmol})$ was added. Radiolabeled $\mathrm{PGE}_{2}$ was separated and analyzed by RP-18 solid phase extraction and HPLC 
analysis. The amount of $11 \beta-\mathrm{PGE}_{2}$ was quantified by integration of the area under the eluted peaks. For quantification of radiolabeled $\mathrm{PGE}_{2}$, fractions $(0.5 \mathrm{ml})$ were collected and mixed with Ultima Gold ${ }^{\mathrm{TM}}$ XR $(2 \mathrm{ml})$ for liquid scintillation counting in a LKB Wallac 1209 Rackbeta Liquid Scintillation Counter.

For determination of 6-keto $\mathrm{PGF}_{1 \alpha}, 1 \times 10^{6}$ cells, resuspended in $1 \mathrm{ml} \mathrm{PBS}$ containing $\mathrm{CaCl}_{2}$ $(1 \mathrm{mM})$, were pre-incubated with the indicated compounds for $15 \mathrm{~min}$ at $37^{\circ} \mathrm{C}$, and 6-keto $\mathrm{PGF}_{1 \alpha}$ formation was initiated by addition of $\mathrm{AA}(30 \mu \mathrm{M})$. After $15 \mathrm{~min}$ at $37^{\circ} \mathrm{C}$, the reaction was stopped by cooling on ice. Cells were centrifuged $\left(300 \times \mathrm{g}, 5 \mathrm{~min}, 4^{\circ} \mathrm{C}\right)$, and the amount of released 6-keto $\mathrm{PGF}_{1 \alpha}$ was assessed by ELISA as described [25].

\subsection{Activity assays of isolated COX-1 and -2}

Inhibition of the activities of isolated ovine COX-1 and human COX-2 was performed as described [25]. Briefly, purified COX-1 (ovine, 50 units) or COX-2 (human recombinant, 20 units) were diluted in $1 \mathrm{ml}$ reaction mixture containing $100 \mathrm{mM}$ Tris buffer $\mathrm{pH} 8,5 \mathrm{mM}$ glutathione, $5 \mu \mathrm{M}$ haemoglobin, and $100 \mu \mathrm{M}$ EDTA at $4{ }^{\circ} \mathrm{C}$ and pre-incubated with the test compounds for $5 \mathrm{~min}$. Samples were pre-warmed for $60 \mathrm{sec}$ at $37{ }^{\circ} \mathrm{C}$, and AA $(5 \mu \mathrm{M}$ for $\mathrm{COX}-1,2 \mu \mathrm{M}$ for $\mathrm{COX}-2$ ) was added to start the reaction. After $5 \mathrm{~min}$ at $37^{\circ} \mathrm{C}$, the COXderived 12-HHT was extracted and then analyzed by HPLC as described [23].

\subsection{Preparation of crude mPGES-1 in microsomes of A549 cells and determination of $\mathrm{PGE}_{2}$ synthase activity}

Preparation of A549 cells and determination of mPGES-1 activity was performed as described [25]. In brief, cells were incubated for $16 \mathrm{~h}$ at $37{ }^{\circ} \mathrm{C}$ and $5 \% \mathrm{CO}_{2}$, the medium was replaced, 
interleukin-1 $\beta(1 \mathrm{ng} / \mathrm{ml})$ was added and cells were incubated for another $48 \mathrm{~h}$. Cells were harvested, frozen in liquid nitrogen, and ice-cold homogenisation buffer $(0.1 \mathrm{M}$ potassium phosphate buffer $\mathrm{pH}$ 7.4, $1 \mathrm{mM}$ phenylmethanesulphonyl fluoride, $60 \mu \mathrm{g} / \mathrm{ml}$ soybean trypsin inhibitor, $1 \mu \mathrm{g} / \mathrm{ml}$ leupeptin, $2.5 \mathrm{mM}$ glutathione, and $250 \mathrm{mM}$ sucrose) was added. After 15 min, cells were sonicated on ice $(3 \times 20 \mathrm{sec})$ and the homogenate was subjected to differential centrifugation at $10,000 \times \mathrm{g}$ for $10 \mathrm{~min}$ and $174,000 \times \mathrm{g}$ for $1 \mathrm{~h}$ at $4{ }^{\circ} \mathrm{C}$. The pellet (microsomal fraction) was resuspended in $1 \mathrm{ml}$ homogenization buffer and the total protein concentration was determined by Coomassie protein assay [26]. Microsomal membranes were diluted in potassium phosphate buffer ( $0.1 \mathrm{M}, \mathrm{pH}$ 7.4) containing $2.5 \mathrm{mM}$ glutathione. Test compounds or vehicle were added and after $15 \min$ at $4{ }^{\circ} \mathrm{C}$, the reaction $(100 \mu \mathrm{l}$ total volume) was initiated by addition of $\mathrm{PGH}_{2}\left(20 \mu \mathrm{M}\right.$, final concentration). After 1 min at $4{ }^{\circ} \mathrm{C}$, the reaction was terminated using stop solution $(100 \mu \mathrm{l} ; 40 \mathrm{mM} \mathrm{FeCl} 2,80 \mathrm{mM}$ citric acid, and $10 \mu \mathrm{M}$ of $\left.11 \beta-\mathrm{PGE}_{2}\right) . \mathrm{PGE}_{2}$ was separated by solid phase extraction on reversed phase (RP)-C18 material using acetonitrile (200 $\mu$ l) as eluent and analyzed by RP-HPLC ( $30 \%$ acetonitrile / $70 \%$ water $+0.007 \%$ TFA $(\mathrm{v} / \mathrm{v}))$ with UV detection at $195 \mathrm{~nm}$. 11ß-PGE ${ }_{2}$ was used as internal standard to quantify $\mathrm{PGE}_{2}$ product formation by integration of the area under the peaks.

\subsection{Determination of $\mathrm{PGE}_{2}$, 6-keto $\mathrm{PGF}_{10}$, and 12-HHT formation in human whole blood}

Peripheral blood from healthy adult volunteers, who had not received any medication for at least two weeks under informed consent, was obtained by venipuncture and collected in syringes containing heparin $(20 \mathrm{U} / \mathrm{ml})$. For determination of $\mathrm{PGE}_{2}$ and 6-keto $\mathrm{PGF}_{1 \alpha}$, aliquots of whole blood $(0.8 \mathrm{ml})$ were mixed with the thromboxane synthase inhibitor CV4151 $(1 \mu \mathrm{M})$ and with aspirin $(50 \mu \mathrm{M})$. A total volume of $1 \mathrm{ml}$ was adjusted with sample buffer $(10 \mathrm{mM}$ 
potassium phosphate buffer $\mathrm{pH} 7.4,3 \mathrm{mM} \mathrm{KCl}, 140 \mathrm{mM} \mathrm{NaCl}$, and $6 \mathrm{mM}$ D-glucose). After pre-incubation with the indicated compounds for $5 \mathrm{~min}$ at room temperature, the samples were stimulated with lipopolysaccharide $(10 \mu \mathrm{g} / \mathrm{ml})$ for $5 \mathrm{~h}$ at $37{ }^{\circ} \mathrm{C}$. Prostanoid formation was stopped on ice, the samples were centrifuged $\left(2300 \times \mathrm{g}, 10 \mathrm{~min}, 4{ }^{\circ} \mathrm{C}\right)$, and 6-keto $\mathrm{PGF}_{1 \alpha}$ was quantified in the supernatant using a 6-keto PGF ${ }_{1 \alpha}$ High Sensitivity EIA Kit (Assay Designs, Ann Arbor, MI) according to the manufacturer's protocol. $\mathrm{PGE}_{2}$ was determined as described [25]. In brief, the supernatant was acidified with citric acid (30 $\mu 1,2 \mathrm{M})$, and after centrifugation $\left(2300 \times \mathrm{g}, 10 \mathrm{~min}, 4{ }^{\circ} \mathrm{C}\right)$, solid phase extraction, and HPLC, analysis of $\mathrm{PGE}_{2}$ was performed to isolate $\mathrm{PGE}_{2}$. The $\mathrm{PGE}_{2}$ peak $(3 \mathrm{ml})$, identified by co-elution with the authentic standard, was collected, and acetonitrile was removed under a nitrogen stream. The $\mathrm{pH}$ was adjusted to 7.2 by addition of $10 \times \mathrm{PBS}$ buffer $\mathrm{pH} 7.2(230 \mu \mathrm{l})$ before $\mathrm{PGE}_{2}$ contents were quantified using a $\mathrm{PGE}_{2}$ High Sensitivity EIA Kit (Assay Designs, Ann Arbor, MI) according to the manufacturer's protocol.

For determination of 12-HHT, human whole blood $(2 \mathrm{ml})$ was pre-incubated with the indicated compounds at $37^{\circ} \mathrm{C}$ for $5 \mathrm{~min}$, and formation of 12 -HHT was initiated by addition of $30 \mu \mathrm{M} \mathrm{Ca}^{2+}$-ionophore $\mathrm{A} 23187$ and $100 \mu \mathrm{M} \mathrm{AA}$. After $10 \mathrm{~min}$ at $37^{\circ} \mathrm{C}$, the reaction was stopped on ice, and the samples were centrifuged $\left(600 \times \mathrm{g} / 10 \mathrm{~min} / 4{ }^{\circ} \mathrm{C}\right)$. Aliquots of the resulting plasma $(500 \mu \mathrm{l})$ were then mixed with $2 \mathrm{ml}$ of methanol, and $200 \mathrm{ng}$ of $\mathrm{PGB}_{1}$ was added as internal standard. The samples were placed at $-20{ }^{\circ} \mathrm{C}$ for $2 \mathrm{~h}$ and centrifuged again $\left(600 \times \mathrm{g} / 15 \mathrm{~min} / 4^{\circ} \mathrm{C}\right)$. The supernatants were collected and diluted with $2.5 \mathrm{ml}$ PBS and $75 \mu \mathrm{l}$ $\mathrm{HCl} 1 \mathrm{~N}$. Formed 12-HHT was extracted and analyzed by HPLC as described [23].

\subsection{Expression of human recombinant 5-lipoxygenase in E.coli, preparation of homogenates and $100,000 \times g$ supernatants, and semi-purification of 5 -lipoxygenase}




\section{protein}

E.coli MV1190 was transformed with pT3-5-LO plasmid, and recombinant 5-LO protein was

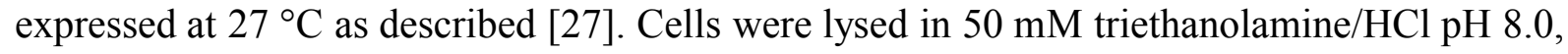
$5 \mathrm{mM}$ EDTA, soybean trypsin inhibitor $(60 \mu \mathrm{g} / \mathrm{ml}), 1 \mathrm{mM}$ phenylmethanesulphonyl fluoride, and lysozyme $(500 \mu \mathrm{g} / \mathrm{ml})$, homogenized by sonication $(3 \times 15 \mathrm{sec})$, and centrifuged at $100,000 \times \mathrm{g}$ for $70 \mathrm{~min}$ at $4{ }^{\circ} \mathrm{C}$. The $100,000 \times \mathrm{g}$ supernatant $(\mathrm{S} 100)$ was applied to an ATPagarose column to partially purify 5-LO as described previously [28]. S100 or semi-purified 5-LO were immediately used for activity assays.

\subsection{Determination of 5-lipoxygenase product formation in cell-free systems}

Aliquots of S100 or semi-purified 5-LO were diluted with ice-cold PBS containing $1 \mathrm{mM}$ EDTA, and $1 \mathrm{mM}$ ATP was added. Samples were pre-incubated with the test compounds as indicated. After $10 \mathrm{~min}$ at $4{ }^{\circ} \mathrm{C}$, samples were pre-warmed for $30 \mathrm{sec}$ at $37^{\circ} \mathrm{C}$, and $2 \mathrm{mM}$ $\mathrm{CaCl}_{2}$ plus $20 \mu \mathrm{M}$ AA was added to start 5 -LO product formation. The reaction was stopped after $10 \mathrm{~min}$ at $37^{\circ} \mathrm{C}$ by addition of $1 \mathrm{ml}$ ice-cold methanol, and the formed metabolites were analyzed by RP-HPLC as described [24]. 5-LO products include the all-trans isomers of LTB $_{4}$ and 5(S)-hydro(pero)xy-6-trans-8,11,14-cis-eicosatetraenoic acid.

\subsection{Determination of 5-lipoxygenase product formation in intact cells}

Freshly isolated neutrophils $\left(5 \times 10^{6} / \mathrm{ml}\right.$ PGC buffer $)$ were pre-incubated with the test compounds for $15 \mathrm{~min}$ at room temperature and 5-LO product formation was started by addition of $2.5 \mu \mathrm{M}$ ionophore $\mathrm{A} 23187$ plus $20 \mu \mathrm{M}$ AA. After 10 min at $37^{\circ} \mathrm{C}$, the reaction was stopped with $1 \mathrm{ml}$ of methanol and $30 \mu \mathrm{l}$ of $1 \mathrm{~N} \mathrm{HCl}$, and then, $200 \mathrm{ng} \mathrm{PGB}_{1}$ and $500 \mu \mathrm{l}$ PBS were added. Formed 5-LO metabolites were extracted and analyzed by HPLC as described [24]. 5-LO products include $\mathrm{LTB}_{4}$ and its all-trans isomers, and 5(S)- 
hydro(pero)xy-6-trans-8,11,14-cis-eicosatetraenoic acid. Cysteinyl-LTs $\mathrm{C}_{4}, \mathrm{D}_{4}$, and $\mathrm{E}_{4}$ were not detected, and oxidation products of $\mathrm{LTB}_{4}$ were not determined.

\subsection{Statistics}

Data are expressed as mean $\pm \mathrm{S}$.E. $\mathrm{IC}_{50}$ values are approximations determined by graphical analysis (linear interpolation between the points between $50 \%$ activity). The program Graphpad Instat (Graphpad Software Inc., San Diego, CA) was used for statistical comparisons. Statistical evaluation of the data was performed by one-way ANOVAs for independent or correlated samples followed by Tukey HSD post-hoc tests. A P value of $<0.05$ (*) was considered significant. 


\section{Results}

\subsection{Effects of garcinol on arachidonic acid release from human neutrophils}

Previously, it was suggested that garcinol interferes with eicosanoid formation at the level of gene expression (COX-2) [8], or ERK1/2 phosphorylation resulting in reduced AA release in lipopolysaccharide-stimulated RAW264.7 murine macrophages [10]. We investigated the effects of garcinol on cellular $\mathrm{cPLA}_{2}$-mediated AA release in human neutrophils using the $\mathrm{Ca}^{2+}$-ionophore $\mathrm{A} 23187$ as stimulus that acts by substantial elevation of $\left[\mathrm{Ca}^{2+}\right]_{\mathrm{i}}$, independent of cellular signalling pathways. Neutrophils, pre-incubated with garcinol (3 to $33 \mu \mathrm{M}$ ), were stimulated with $\mathrm{Ca}^{2+}$-ionophore $(2.5 \mu \mathrm{M})$, and the released AA was derivatized with 2,4dimethoxyaniline and analyzed by RP-HPLC. Garcinol failed to significantly suppress the release of AA up to $33 \mu \mathrm{M}$ (Fig. 1B), whereas the $\mathrm{cPLA}_{2} \alpha$-inhibitor (control) potently inhibited AA liberation.

\subsection{Effects of garcinol on cellular prostanoid formation}

Next, we investigated the effects of garcinol on the transformation of AA to prostanoids in intact cells. Prostanoid formation was initiated by addition of exogenous AA in order to circumvent endogenous AA supply, and thus, to exclude inhibition of prostanoid formation at the level of $\mathrm{PLA}_{2}$-mediated substrate release. For determination of COX-1 inhibition, human platelets were pre-incubated with garcinol (1 to $33 \mu \mathrm{M})$, and formation of COX-1-derived $\mathrm{TxB}_{2}$ and 12-HHT (non-enzymatically formed from $\mathrm{PGH}_{2}$ in platelets [29]) was initiated by AA $(5 \mu \mathrm{M})$. Garcinol significantly suppressed $\mathrm{TxB}_{2}$ (Fig. 1C) and 12-HHT (Fig. 1D) formation at $10 \mu \mathrm{M}$ with an $\mathrm{IC}_{50}$ of 16 and $11 \mu \mathrm{M}$, respectively. To investigate inhibition of cellular COX-2 activity, we assessed the formation of $\mathrm{PGE}_{2}$ and the stable $\mathrm{PGI}_{2}$ degradation 
product 6-keto $\mathrm{PGF}_{1 \alpha}$ (as biomarker for $\mathrm{PGI}_{2}$ formation) in $\mathrm{A} 549$ cells. For measuring 6-keto $\mathrm{PGF}_{1 \alpha}$, higher concentrations of $\mathrm{AA}(30$ instead of $1 \mu \mathrm{M})$ were required than for determination of $\mathrm{PGE}_{2}$ to get detectable amounts of 6-keto $\mathrm{PGF}_{1 \alpha}$ (detection limit: $14 \mathrm{ng} / \mathrm{ml}$ at a signal to noise ratio of 3). A contribution of COX-1 can be excluded in interleukin-1 $\beta$ stimulated A549 cells because COX-1 is neither detectable on the protein nor on the RNA level [30, 31]. COX-2-mediated synthesis of $\mathrm{PGE}_{2}$ was significantly inhibited at $10 \mu \mathrm{M}$ with an apparent $\mathrm{IC}_{50}$ of approx. $10 \mu \mathrm{M}$ (Fig. 2A), whereas the synthesis of 6-keto $\mathrm{PGF}_{1 \alpha}$ was not significantly reduced by garcinol up to $33 \mu \mathrm{M}$ (Fig. 2B). $\mathrm{PGE}_{2}$ formation is inhibited by garcinol within a narrow concentration range (3 to $10 \mu \mathrm{M}$ ), and higher concentrations of garcinol failed to completely block $\mathrm{PGE}_{2}$ synthesis. Also MK-886 (33 $\left.\mu \mathrm{M}\right)$, a mPGES-1 inhibitor, did not interfere with 6-keto $\mathrm{PGF}_{1 \alpha}$ synthesis and failed to entirely suppress $\mathrm{PGE}_{2}$ formation [25]. In contrast, the COX-2 inhibitor celecoxib $(5 \mu \mathrm{M})$ efficiently suppressed both formation of $\mathrm{PGE}_{2}$ (Fig. 2A) and 6-keto $\mathrm{PGF}_{1 \alpha}$ (Fig. 2B), respectively.

\subsection{Effects of garcinol on the activity of $\mathrm{COX}-1 / 2$ in cell-free assays}

We determined whether garcinol may directly interfere with the catalytic activity of isolated COX-1 and/or COX-2. The formation of 12-HHT, the major COX-1/2-derived product under the experimental conditions chosen [32], was initiated by addition of AA ( $5 \mu \mathrm{M}$ for COX-1, 2 $\mu \mathrm{M}$ for COX-2). Garcinol concentration-dependently and significantly inhibited COX-1mediated 12-HHT formation at $10 \mu \mathrm{M}$ with an $\mathrm{IC}_{50}=12 \mu \mathrm{M}$, which is in good agreement with the efficacy in intact platelets ( $\mathrm{IC}_{50}=11 \mu \mathrm{M}$, see above). In contrast, COX-2 activity was not significantly reduced up to $33 \mu \mathrm{M}$ (Fig. 3A). Indomethacin (10 $\mu \mathrm{M}$, for COX-1) and celecoxib (5 $\mu \mathrm{M}$, for COX-2), used as reference compounds, potently inhibited 12-HHT formation, as expected (Fig. 3B). 


\subsection{Effects of garcinol on the activity of mPGES-1}

Because garcinol failed to inhibit COX-2 in cell-free assays and did not suppress 6-keto $\mathrm{PGF}_{1 \alpha}$ synthesis in $\mathrm{A} 549$ cells but reduced $\mathrm{PGE}_{2}$ formation, it appeared reasonable that garcinol might selectively suppress $\mathrm{PGE}_{2}$ formation via inhibition of $\mathrm{PGE}_{2}$ synthases downstream of COX-2. Microsomal preparations of interleukin-1 $\beta$-stimulated A549 cells, used as source of mPGES-1 [33], were pre-incubated with garcinol or vehicle (DMSO) for 15 min, and then, $\mathrm{PGE}_{2}$ formation was initiated by addition of $20 \mu \mathrm{M} \mathrm{PGH}_{2}$. In agreement with the literature $[25,34]$, the mPGES-1 inhibitor MK-886 (used as control) inhibited PGE $_{2}$ formation with an $\mathrm{IC}_{50}$ of $2.1 \mu \mathrm{M}$ (data not shown). Garcinol was slightly superior over MK886 and concentration-dependently inhibited $\mathrm{PGE}_{2}$ formation with an $\mathrm{IC}_{50}$ of $1.2 \mu \mathrm{M}$ (Fig. 4A). Decreasing the $\mathrm{PGH}_{2}$ concentration to $1 \mu \mathrm{M}$ even enhanced the potency of garcinol to suppress mPGES-1 activity $\left(\mathrm{IC}_{50}=0.3 \mu \mathrm{M}\right.$, Fig. 4B) suggesting a substrate competitive inhibitory mechanism.

To investigate whether garcinol inhibits $\mathrm{PGE}_{2}$ synthesis in a reversible manner, microsomal preparations of A549 cells were pre-incubated with garcinol and MK-886, and wash-out experiments were carried out. MK-886 and garcinol failed to efficiently block $\mathrm{PGE}_{2}$ synthesis at $0.3 \mu \mathrm{M}$, whereas $\mathrm{PGE}_{2}$ formation was efficiently inhibited at $3 \mu \mathrm{M}$ (Fig. 4C). However, 10-fold dilution of the samples containing $3 \mu \mathrm{M}$ garcinol and MK-886 restored mPGES-1 activity (Fig. 4C) implying a reversible mode of inhibition.

\subsection{Effects of garcinol on prostanoid formation in human whole blood}

Many potent inhibitors of prostanoid biosynthesis in cell-free assays or in intact isolated cells lose their efficacy under physiologically relevant conditions such as in whole blood. 
Therefore, we investigated whether garcinol could affect prostanoid biosynthesis also in a human whole blood assay. To assess inhibition of COX-1, freshly drawn human venous blood was pre-incubated with the test compounds or vehicle (DMSO) for $5 \mathrm{~min}$ and then treated with $\mathrm{Ca}^{2+}$-ionophore plus AA $(100 \mu \mathrm{M})$. Formation of 12-HHT, which mainly derives from constitutively expressed COX-1 under these experimental conditions, was not significantly affected by garcinol up to $33 \mu \mathrm{M}$ (Fig. 5A). In control experiments, indomethacin $(20 \mu \mathrm{M})$ almost completely blocked 12-HHT synthesis.

For determination of COX-2 inhibition, heparinized blood was pre-incubated with garcinol or vehicle (5 min) and stimulated with lipopolysaccharide for $5 \mathrm{~h}$. Then, the levels of $\mathrm{PGE}_{2}$ and 6-keto $\mathrm{PGF}_{1 \alpha}$ were determined in the corresponding plasma by ELISA. For measuring $\mathrm{PGE}_{2}$ levels, $\mathrm{PGE}_{2}$ was first separated from other AA metabolites by RP-HPLC [25]. In agreement with the results obtained with A549 cells, garcinol suppressed $\mathrm{PGE}_{2}$ formation in whole blood in a concentration-dependent manner starting at $3 \mu \mathrm{M}$ with an apparent $\mathrm{IC}_{50}$ value of $30 \mu \mathrm{M}$ (Fig. 5B). Significant inhibition of $\mathrm{PGE}_{2}$ formation was only reached at $30 \mu \mathrm{M}$ for both garcinol and the mPGES-1 reference inhibitor MK-886, and also prolonged stimulation of whole blood with LPS up to $24 \mathrm{~h}$ did not increase the potency of garcinol. Neither garcinol nor MK-886 reduced 6-keto $\mathrm{PGF}_{1 \alpha}$ formation up to $30 \mu \mathrm{M}$ under the same conditions, suggesting a selective interference of garcinol with $\mathrm{PGE}_{2}$ synthesis (Fig. 5C). Note that garcinol as well as MK-886 were less efficient in inhibiting $\mathrm{PGE}_{2}$ formation as compared to indomethacin or celecoxib.

\subsection{Inhibition of 5-lipoxygenase product formation by garcinol}

To determine the effects of garcinol on 5-LO product formation in intact cells, freshly isolated human neutrophils were pre-incubated with garcinol for $15 \mathrm{~min}$ and 5-LO product synthesis 
was initiated by $\mathrm{Ca}^{2+}$-ionophore $\mathrm{A} 23187(2.5 \mu \mathrm{M})$ plus exogenous $\mathrm{AA}(20 \mu \mathrm{M})$. 5-LO product formation was concentration-dependently inhibited by garcinol with an $\mathrm{IC}_{50}=1.9 \mu \mathrm{M}$ (Fig. 6A). Differences in the potency of garcinol to inhibit the formation of $\mathrm{LTB}_{4}$ (formed via $\mathrm{LTA}_{4}$ hydrolase) and 5(S)-hydro(pero)xy-6-trans-8,11,14-cis-eicosatetraenoic acid $\left(\mathrm{IC}_{50}=1.5\right.$ and $1.8 \mu \mathrm{M}$, respectively) were not observed, excluding an interference of garcinol with $\mathrm{LTA}_{4}$ hydrolase at these concentrations. The efficiency of garcinol was somewhat improved in a cell-free assay using $100,000 \times \mathrm{g}$ supernatant of homogenized neutrophils as source of enzyme $\left(\mathrm{IC}_{50}=0.5 \mu \mathrm{M}\right.$, Fig. 6B) and was even higher for semi-purified recombinant 5-LO $\left(\mathrm{IC}_{50}=0.1\right.$ $\mu \mathrm{M}$, Fig. 6C). In contrast, the iron-ligand type 5-LO inhibitor BWA4C (1 $\mu \mathrm{M}$, used as control) was equally effective independent of the assay conditions (data not shown). 


\section{Discussion}

Animal studies have revealed an anti-carcinogenic potential of garcinol [2, 3], and in vitro studies have demonstrated potent growth-inhibitory and apoptotic $[5,6]$ as well as antioxidant [4] and anti-inflammatory effects [8, 10]. Interference with lipopolysaccharideinduced NFאB signalling, lowering COX-2 and iNOS expression, may explain the long-term anti-inflammatory and anti-carcinogenic effects of garcinol [8], whereas the short term effects were ascribed to impaired cPLA 2 activation through inhibition of ERK-1/2 phosphorylation restricting the supply of AA for eicosanoid formation [10]. Although suppression of eicosanoid formation may be a crucial mode of action of garcinol, direct inhibitory effects on enzymes involved in eicosanoid biosynthesis have not been investigated yet.

Our data demonstrate that garcinol is a direct and potent inhibitor of purified 5-LO and cellfree mPGES- 1 with $\mathrm{IC}_{50}=0.1$ and $0.3 \mu \mathrm{M}$, respectively, and also a direct inhibition of COX1 by garcinol is evident. Inhibition of other molecular targets (i.e., histone acetyltransferase p300 [11], P300/CBP-associated factor [11], and acetylcholine esterase [12]) required higher concentrations of garcinol $\left(\mathrm{IC}_{50}=0.7\right.$ to $\left.7 \mu \mathrm{M}\right)$. However, because of the different experimental settings applied for analysis of the interference of garcinol with these targets, direct comparison of garcinol's potencies is difficult. 5-LO and mPGES-1 are crucial enzymes in the biosynthesis of key mediators in inflammatory processes [16, 19], providing a rationale for the anti-inflammatory effects of garcinol. Moreover, 5-LO and mPGES-1 are overexpressed in many tumors, and $\mathrm{PGE}_{2}$ as well as 5-LO products play important roles in tumorigenesis $[16,18,19]$. Together, we conclude that the interference of garcinol with 5-LO and mPGES-1 provides a molecular basis for its documented anti-carcinogenic and antiinflammatory properties. 
Inhibition of 5-LO and mPGES-1 is evident also in intact cell assays and in human whole blood. On the other hand, inhibition of COX-1-derived 12-HHT formation in human whole blood was minute and not significant up to $33 \mu \mathrm{M}$, although COX-1 activity is obviously inhibited in intact platelets and in the cell-free assay $\left(\mathrm{IC}_{50}=11\right.$ and $12 \mu \mathrm{M}$, respectively). This loss of potency in whole blood might be related to albumin-binding of garcinol but also to competition with high AA concentrations (that are required in whole blood for analysis of 12HHT formation) for binding to the active site of COX-1.

The experimental settings (stimuli used, availability of respective substrates, and products determined) of these cell-based assays allowed us to attribute the effects of garcinol to the interference with the putative targets and to exclude other points of attack. In particular, garcinol may simply block the supply of AA by interference with cPLA 2 activity, an enzyme, whose activation and cellular functionality has been previously proposed to be affected by garcinol [10]. Hong et al. showed that in lipopolysaccharide-stimulated RAW264.7 murine macrophages garcinol blocked AA release by impairing the activation of $\mathrm{cPLA}_{2}$. This was ascribed to the interference with defined signalling steps (i.e., ERK signalling, phosphorylation of $\mathrm{cPLA}_{2}$ ) [10]. To circumvent such signalling pathways for $\mathrm{cPLA}_{2}$ activation, we challenged human neutrophils with the $\mathrm{Ca}^{2+}$-ionophore $\mathrm{A} 23187$, where the massive increase in intracellular $\mathrm{Ca}^{2+}$ essentially stimulates $\mathrm{CPLA}_{2}$. Garcinol failed to block AA liberation under these experimental conditions, indicating that $\mathrm{PLA}_{2}$-mediated AA release is not generally inhibited by garcinol. Note that in our cell-based assays analyzing AA transformations by $\mathrm{COX}-1 / 2$ or by $5-\mathrm{LO}$, AA was exogenously supplemented to avoid effects on eicosanoid formation due to inhibition of $\mathrm{PLA}_{2}$. On the other hand, the effects of garcinol on $\mathrm{PGE}_{2}$ and 6-keto $\mathrm{PGF}_{1 \alpha}$ formation in whole blood were analyzed under conditions (lipopolysaccharide challenge) where AA was supplied by endogenous sources. In contrast to $\mathrm{PGE}_{2}$ formation, the synthesis of 6-keto $\mathrm{PGF}_{1 \alpha}$ was unaffected by garcinol, excluding general 
suppression of $\mathrm{AA}$ and suggesting $\mathrm{PGE}_{2}$ synthase (i.e., mPGES-1) as molecular target of garcinol. However, our data cannot exclude that garcinol also inhibits other $\mathrm{PGE}_{2}$ synthases (such as cytosolic $\mathrm{PGE}_{2}$ synthase or mPGES-2) in addition to mPGES-1.

$\mathrm{PGE}_{2}$ and 6-keto $\mathrm{PGF}_{1 \alpha}$ are synthesized via the COX-2 pathway in lipopolysaccharidestimulated whole blood [35]. Because 6-keto $\mathrm{PGF}_{1 \alpha}$ formation in whole blood was unaffected by garcinol, our data imply that garcinol-mediated suppression of $\mathrm{PGE}_{2}$ synthesis in the same assay is independent of an interference with COX-2. Also, garcinol failed to inhibit isolated COX-2. Co-expression studies have revealed a preferred functional coupling of COX-2 and mPGES-1 [36] suggesting that mPGES-1 is the major contributing $\mathrm{PGE}_{2}$ synthase for $\mathrm{PGE}_{2}$ synthesis in lipopolysaccharide-stimulated blood. Nevertheless, in analogy to other mPGES-1 inhibitors [25], garcinol failed to completely suppress $\mathrm{PGE}_{2}$ synthesis in whole blood and the remaining $\mathrm{PGE}_{2}$ synthesis of approx. $40 \%$ might be attributable to other $\mathrm{PGE}_{2}$ synthases (i.e., cytosolic $\mathrm{PGE}_{2}$ synthase or mPGES-2) [25].

For inhibition of purified 5-LO $\left(\mathrm{IC}_{50}=0.1 \mu \mathrm{M}\right)$ and cellular 5-LO product formation $\left(\mathrm{IC}_{50}=\right.$ $1.9 \mu \mathrm{M}$ ), a discrepancy in the potencies of garcinol was obvious. Interestingly, a similar pattern was found for the structurally related hyperforin [23] that possesses an unique inhibitory mode of action by interfering with the membrane-binding region of 5-LO's C2-like domain (Feißt et al., 2009, manuscript submitted). However, garcinol is an effective antioxidant [4] and may act as redox-type inhibitor of 5-LO reducing the active site iron. Such reduction might be more vigorous for cell-free 5-LO as compared to intracellular enzyme, a common phenomenon observed for many redox-active 5-LO inhibitors [37].

Despite the obvious inhibition of $\mathrm{PGE}_{2}$ and LT formation by garcinol in vitro, the question whether the interference of garcinol with mPGES-1 and 5-LO accounts for its anti- 
inflammatory and anti-tumorigenic properties in vivo, can not be clearly answered yet. Unpublished studies, mentioned by Hong et al. [10], showed that garcinol inhibited phorbol myristate acetate-induced mouse ear edema accompanied by decreased $\mathrm{PGE}_{2}$ and $\mathrm{LTB}_{4}$ production. Of interest, in these experiments the peak plasma levels of garcinol $(12 \mu \mathrm{M})$ obtained after oral application of garcinol were in a concentration range, where cellular inhibition 5-LO and mPGES-1 is evident in our study. Therefore, one may speculate that garcinol, after oral administration, could achieve plasma levels sufficient to markedly suppress $\mathrm{PGE}_{2}$ and LT biosynthesis under inflammatory conditions. $\mathrm{PGE}_{2}$ is one of the mostestablished key players in the initiation and progression of inflammation [38], and NSAIDs exert their beneficial effects in vivo essentially by repressing $\mathrm{PGE}_{2}$ formation [13]. Animals deficient in COX-2 or mPGES-1 clearly show reduced inflammatory symptoms [19, 39]. Moreover, $\mathrm{LTB}_{4}$ is a potent chemotactic and chemokinetic agent that recruits proinflammatory cells towards sites of inflammation [40]. But also tumorigenesis, particularly of colon, breast, prostate, and lung carcinoma has been associated with excessive $\mathrm{PGE}_{2}$ and LT formation $[16,18,19]$. COX-2 selective inhibitors have shown a chemopreventive potential [41], and mPGES-1 is overexpressed in various cancers such as non-small cell lung cancer, invasive breast cancer, colorectal cancer, and gastric cancer [19]. Also 5-LO and its helperprotein FLAP are overexpressed in cancer cells, and 5-LO products promote cell proliferation and/or inhibit apoptosis, whereas 5-LO or FLAP inhibitors caused cell death [18].

In conclusion, we have identified human mPGES-1 and 5-LO as molecular targets of garcinol, and we showed that garcinol potently interferes with the catalytic activity of these enzymes in cell-free and cell-based assays. Inhibition of mPGES-1 and 5-LO may contribute to the anti-carcinogenic and anti-inflammatory effectiveness of garcinol observed in previous studies. Our data indicate that garcinol exerts a promising pharmacological profile combining potent inhibition of $\mathrm{PGE}_{2}$ and $\mathrm{LT}$ formation without marked inhibition of $\mathrm{COX}$ isoenzymes. 


\section{References}

[1] Krishnamurthy N, Lewis YS, Ravindranath B. On the structures of garcinol, isogarcinol and camboginol. Tetrahedron Letters 1981;22:793-6.

[2] Yoshida K, Tanaka T, Hirose Y, Yamaguchi F, Kohno H, Toida M, et al. Dietary garcinol inhibits 4-nitroquinoline 1-oxide-induced tongue carcinogenesis in rats. Cancer Lett 2005;221:29-39.

[3] Tanaka T, Kohno H, Shimada R, Kagami S, Yamaguchi F, Kataoka S, et al. Prevention of colonic aberrant crypt foci by dietary feeding of garcinol in male F344 rats. Carcinogenesis 2000;21:1183-9.

[4] Yamaguchi F, Ariga T, Yoshimura Y, Nakazawa H. Antioxidative and anti-glycation activity of garcinol from Garcinia indica fruit rind. J Agric Food Chem 2000;48:180-5.

[5] Hong J, Kwon SJ, Sang S, Ju J, Zhou JN, Ho CT, et al. Effects of garcinol and its derivatives on intestinal cell growth: Inhibitory effects and autoxidation-dependent growth-stimulatory effects. Free Radic Biol Med 2007;42:1211-21.

[6] Pan MH, Chang WL, Lin-Shiau SY, Ho CT, Lin JK. Induction of apoptosis by garcinol and curcumin through cytochrome c release and activation of caspases in human leukemia HL-60 cells. J Agric Food Chem 2001;49:1464-74.

[7] Liao CH, Sang S, Ho CT, Lin JK. Garcinol modulates tyrosine phosphorylation of FAK and subsequently induces apoptosis through down-regulation of Src, ERK, and Akt survival signaling in human colon cancer cells. J Cell Biochem 2005;96:155-69.

[8] Liao CH, Sang S, Liang YC, Ho CT, Lin JK. Suppression of inducible nitric oxide synthase and cyclooxygenase-2 in downregulating nuclear factor-kappa B pathway by Garcinol. Mol Carcinog 2004;41:140-9. 
[9] Matsumoto K, Akao Y, Kobayashi E, Ito T, Ohguchi K, Tanaka T, et al. Cytotoxic benzophenone derivatives from Garcinia species display a strong apoptosis-inducing effect against human leukemia cell lines. Biol Pharm Bull 2003;26:569-71.

[10] Hong J, Sang S, Park HJ, Kwon SJ, Suh N, Huang MT, et al. Modulation of arachidonic acid metabolism and nitric oxide synthesis by garcinol and its derivatives. Carcinogenesis 2006;27:278-86.

[11] Balasubramanyam K, Altaf M, Varier RA, Swaminathan V, Ravindran A, Sadhale PP, et al. Polyisoprenylated benzophenone, garcinol, a natural histone acetyltransferase inhibitor, represses chromatin transcription and alters global gene expression. J Biol Chem 2004;279:33716-26.

[12] Lenta BN, Vonthron-Senecheau C, Weniger B, Devkota KP, Ngoupayo J, Kaiser M, et al. Leishmanicidal and cholinesterase inhibiting activities of phenolic compounds from Allanblackia monticola and Symphonia globulifera. Molecules 2007;12:1548-57.

[13] Funk CD. Prostaglandins and leukotrienes: advances in eicosanoid biology. Science 2001;294:1871-5.

[14] Zha S, Yegnasubramanian V, Nelson WG, Isaacs WB, De Marzo AM. Cyclooxygenases in cancer: progress and perspective. Cancer Lett 2004;215:1-20.

[15] Gupta S, Srivastava M, Ahmad N, Sakamoto K, Bostwick DG, Mukhtar H. Lipoxygenase-5 is overexpressed in prostate adenocarcinoma. Cancer 2001;91:73743.

[16] Werz O, Steinhilber D. Therapeutic options for 5-lipoxygenase inhibitors. Pharmacol Ther 2006;112:701-18.

[17] Gasparini G, Longo R, Sarmiento R, Morabito A. Inhibitors of cyclo-oxygenase 2: a new class of anticancer agents? Lancet Oncol 2003;4:605-15. 
[18] Chen X, Sood S, Yang CS, Li N, Sun Z. Five-lipoxygenase pathway of arachidonic acid metabolism in carcino-genesis and cancer chemoprevention. Curr Cancer Drug Targets 2006;6:613-22.

[19] Samuelsson B, Morgenstern R, Jakobsson PJ. Membrane prostaglandin E synthase-1: a novel therapeutic target. Pharmacol Rev 2007;59:207-24.

[20] Cote B, Boulet L, Brideau C, Claveau D, Ethier D, Frenette R, et al. Substituted phenanthrene imidazoles as potent, selective, and orally active mPGES-1 inhibitors. Bioorg Med Chem Lett 2007;17:6816-20.

[21] Xu D, Rowland SE, Clark P, Giroux A, Cote B, Guiral S, et al. MF63 \{2-(6-chloro1H-phenanthro[9,10-d]imidazol-2-yl)isophthalonitrile\}, a selective microsomal prostaglandin E synthase 1 inhibitor, relieves pyresis and pain in preclinical models of inflammation. J Pharmacol Exp Ther 2008;326:754-63.

[22] Kato K, Ohkawa S, Terao S, Terashita Z, Nishikawa K. Thromboxane synthetase inhibitors (TXSI). Design, synthesis, and evaluation of a novel series of omegapyridylalkenoic acids. J Med Chem 1985;28:287-94.

[23] Albert D, Zundorf I, Dingermann T, Muller WE, Steinhilber D, Werz O. Hyperforin is a dual inhibitor of cyclooxygenase-1 and 5-lipoxygenase. Biochem Pharmacol $2002 ; 64: 1767-75$.

[24] Werz O, Burkert E, Samuelsson B, Rådmark O, Steinhilber D. Activation of 5lipoxygenase by cell stress is calcium independent in human polymorphonuclear leukocytes. Blood 2002;99:1044-52.

[25] Koeberle A, Siemoneit U, Buehring U, Northoff H, Laufer S, Albrecht W, et al. Licofelone suppresses prostaglandin E2 formation by interference with the inducible microsomal prostaglandin E2 synthase-1. J Pharmacol Exp Ther 2008;326:975-82. 
[26] Bradford MM. A rapid and sensitive method for the quantitation of microgram quantities of protein utilizing the principle of protein-dye binding. Anal Biochem $1976 ; 72: 248-54$

[27] Fischer L, Szellas D, Rådmark O, Steinhilber D, Werz O. Phosphorylation- and stimulus-dependent inhibition of cellular 5-lipoxygenase activity by nonredox-type inhibitors. FASEB J 2003;17:949-51.

[28] Burkert E, Arnold C, Hammarberg T, Rådmark O, Steinhilber D, Werz O. The C2-like beta-barrel domain mediates the $\mathrm{Ca} 2+$-dependent resistance of 5-lipoxygenase activity against inhibition by glutathione peroxidase-1. J Biol Chem 2003;278:42846-53.

[29] Hamberg M, Samuelsson B. Prostaglandin endoperoxides. Novel transformations of arachidonic acid in human platelets. Proc Natl Acad Sci U S A 1974;71:3400-4.

[30] Asano K, Lilly CM, Drazen JM. Prostaglandin G/H synthase-2 is the constitutive and dominant isoform in cultured human lung epithelial cells. Am J Physiol 1996;271:L126-31.

[31] Thoren S, Jakobsson PJ. Coordinate up- and down-regulation of glutathionedependent prostaglandin E synthase and cyclooxygenase-2 in A549 cells. Inhibition by NS-398 and leukotriene C4. Eur J Biochem 2000;267:6428-34.

[32] Capdevila JH, Morrow JD, Belosludtsev YY, Beauchamp DR, DuBois RN, Falck JR. The catalytic outcomes of the constitutive and the mitogen inducible isoforms of prostaglandin $\mathrm{H} 2$ synthase are markedly affected by glutathione and glutathione peroxidase(s). Biochemistry 1995;34:3325-37.

[33] Jakobsson PJ, Thoren S, Morgenstern R, Samuelsson B. Identification of human prostaglandin E synthase: a microsomal, glutathione-dependent, inducible enzyme, constituting a potential novel drug target. Proc Natl Acad Sci U S A 1999;96:7220-5.

[34] Claveau D, Sirinyan M, Guay J, Gordon R, Chan CC, Bureau Y, et al. Microsomal prostaglandin E synthase-1 is a major terminal synthase that is selectively up- 
regulated during cyclooxygenase-2-dependent prostaglandin E2 production in the rat adjuvant-induced arthritis model. J Immunol 2003;170:4738-44.

[35] Patrignani P, Panara MR, Greco A, Fusco O, Natoli C, Iacobelli S, et al. Biochemical and pharmacological characterization of the cyclooxygenase activity of human blood prostaglandin endoperoxide synthases. J Pharmacol Exp Ther 1994;271:1705-12.

[36] Murakami M, Naraba H, Tanioka T, Semmyo N, Nakatani Y, Kojima F, et al. Regulation of prostaglandin E2 biosynthesis by inducible membrane-associated prostaglandin E2 synthase that acts in concert with cyclooxygenase-2. J Biol Chem $2000 ; 275: 32783-92$.

[37] Werz O. Inhibition of 5-lipoxygenase product synthesis by natural compounds of plant origin. Planta Med 2007;73:1331-57.

[38] Smith WL. The eicosanoids and their biochemical mechanisms of action. Biochem J $1989 ; 259: 315-24$

[39] Langenbach R, Loftin CD, Lee C, Tiano H. Cyclooxygenase-deficient mice. A summary of their characteristics and susceptibilities to inflammation and carcinogenesis. Ann N Y Acad Sci 1999;889:52-61.

[40] Claesson HE, Dahlen SE. Asthma and leukotrienes: antileukotrienes as novel antiasthmatic drugs. J Intern Med 1999;245:205-27.

[41] Rao CV, Reddy BS. NSAIDs and chemoprevention. Curr Cancer Drug Targets $2004 ; 4: 29-42$. 


\section{Acknowledgments}

The authors thank Bianca Jazzar and Gertrud Kleefeld for expert technical assistance. The financial support by the Deutsche Forschungsgemeinschaft is acknowledged.

Conflict of Interest Statement: None declared. 


\section{Figure Legends}

\section{Fig. 1. Effects of garcinol on cellular arachidonic acid release and prostanoid formation.}

(A) Chemical structure of garcinol. (B) AA release from neutrophils. Neutrophils $\left(3 \times 10^{7} / \mathrm{ml}\right.$ PGC buffer) were pre-incubated with the indicated concentrations of garcinol or vehicle (DMSO, w/o) for $10 \mathrm{~min}$. Then, AA release was initiated by $\mathrm{Ca}^{2+}$-ionophore $(2.5 \mu \mathrm{M})$. After 5 min at $37^{\circ} \mathrm{C}$, AA was coupled to 2,4-dimethoxyaniline and analyzed by HPLC as described in the experimental section. In the absence of test compounds (100\%, control), $180 \mathrm{ng} / \mathrm{ml} \mathrm{AA}$ were released. cPLA 2 -inhibitor $(10 \mu \mathrm{M})$ was used as control. (C) $\mathrm{TxB}_{2}$ and (D) 12-HHT formation in intact platelets. Platelets $\left(10^{8} / \mathrm{ml}\right.$ PBS containing $\left.1 \mathrm{mM} \mathrm{CaCl} 2\right)$ were preincubated with the indicated concentrations of garcinol or vehicle (DMSO, w/o) for 5 min prior to stimulation with AA $(5 \mu \mathrm{M})$. After another 5 min at $37^{\circ} \mathrm{C}$, the formation of $\mathrm{TxB}_{2}$ was assessed by ELISA. $\mathrm{TxB}_{2}$ formed in the absence of test compounds (100\%, control) was 360 $\mathrm{ng} / \mathrm{ml}$. The formation of 12-HHT was determined by RP-HPLC as described. 12-HHT formed in the absence of test compounds (100\%, control) was $290 \mathrm{ng} / \mathrm{ml}$. Indomethacin (Indo, 10 $\mu \mathrm{M})$ was used as control. Data are given as mean + - S.E., $\mathrm{n}=3,{ }^{* *} p<0.01$ or ${ }^{* * *} p<0.001$ vs. vehicle (0.1\% DMSO) control, ANOVA + Tukey HSD post-hoc tests.

Fig. 2. Effects of garcinol on cellular arachidonic acid release and prostanoid formation.

(A) $\mathrm{PGE}_{2}$ formation in A549 cells. Interleukin- $1 \beta$-stimulated A549 cells $\left(4 \times 10^{6} / \mathrm{ml}\right)$ were pre-incubated with garcinol or vehicle (DMSO, w/o) for $10 \mathrm{~min}$, and then, $2.5 \mu \mathrm{M}$ A23187 plus $1 \mu \mathrm{M}$ AA and $[3 \mathrm{H}] \mathrm{AA}(18.4 \mathrm{kBq})$ were added. After 15 min at $37^{\circ} \mathrm{C}$, formed $\left[{ }^{3} \mathrm{H}\right] \mathrm{PGE}_{2}$ was analyzed by RP-HPLC and liquid scintillation counting as described. The $100 \%$ value corresponds to $30 \mathrm{ng} / \mathrm{ml} \mathrm{PGE} 2$. MK-886 $(33 \mu \mathrm{M})$ and celecoxib (Cele, $5 \mu \mathrm{M})$ were used as 
controls. (B) 6-Keto PGF ${ }_{1 \alpha}$ formation in A549 cells. Interleukin-1 $\beta$-stimulated A549 cells (1 $\times 10^{6} / \mathrm{ml}$ ) were pre-incubated with the indicated concentrations of garcinol or vehicle (DMSO) for $15 \mathrm{~min}$ prior to addition of $30 \mu \mathrm{M}$ AA. After $15 \mathrm{~min}$ at $37{ }^{\circ} \mathrm{C}$ the amount of 6keto $\mathrm{PGF}_{1 \alpha}$ was assessed by ELISA as described. The $100 \%$ value corresponds to $70 \mathrm{ng} / \mathrm{ml} 6-$ keto $\mathrm{PGF}_{1 \alpha}$. Indomethacin (Indo, $10 \mu \mathrm{M}$ ) and celecoxib (Cele, $\left.5 \mu \mathrm{M}\right)$ were used as control. Data are given as mean $+/$ S.E., $\mathrm{n}=3, * p<0.05, * * p<0.01$ or $* * * p<0.001$ vs. vehicle $(0.1 \%$ DMSO) control, ANOVA + Tukey HSD post-hoc tests.

\section{Fig. 3. Effects of garcinol on the activity of isolated COX-1 and $\mathbf{- 2}$.}

(A) Purified ovine COX-1 (50 units) or (B) human recombinant COX-2 (20 units) were added to a $\mathrm{COX}$ reaction mix, containing $5 \mathrm{mM}$ glutathione. After pre-incubation with the test compounds or vehicle (DMSO, w/o) for $5 \mathrm{~min}$, the reaction was started with $5 \mu \mathrm{M}(\mathrm{COX}-1)$ or $2 \mu \mathrm{M}(\mathrm{COX}-2) \mathrm{AA}$. After $5 \mathrm{~min}$ at $37^{\circ} \mathrm{C}$, the formation of 12-HHT was determined by RP-HPLC as described. The $100 \%$ values correspond to $80(\mathrm{COX}-1)$ or $70(\mathrm{COX}-2) \mathrm{ng} / \mathrm{ml}$ 12-HHT. Indomethacin (Indo, $10 \mu \mathrm{M}$ ) and celecoxib (Cele, $5 \mu \mathrm{M}$ ) were used as controls. Data are given as mean $+/-$ S.E., $n=3,{ }^{* *} \mathrm{p}<0.01, * * * \mathrm{p}<0.001$ vs. vehicle $(0.1 \%$ DMSO $)$ control, ANOVA + Tukey HSD post-hoc tests.

\section{Fig. 4. Effects of garcinol on the activity of mPGES-1.}

(A) Concentration-response curves for garcinol. Microsomal preparations of interleukin-1 $\beta$ stimulated A549 cells were pre-incubated with vehicle (DMSO) or the test compounds at the indicated concentrations for $15 \mathrm{~min}$ at $4{ }^{\circ} \mathrm{C}$, and the reaction was started with $20 \mu \mathrm{M} \mathrm{PGH}_{2}$. After $1 \mathrm{~min}$ at $4{ }^{\circ} \mathrm{C}$, the reaction was terminated using a stop solution containing $\mathrm{FeCl}_{2}$ and $11 \beta-\mathrm{PGE}_{2}(1 \mathrm{nmol})$ as internal standard. The $100 \%$ value corresponds to $0.8 \mathrm{nmol} \mathrm{PGE}_{2}$. (B) 
The potency of garcinol for mPGES-1 inhibition was compared at 1 and $20 \mu \mathrm{M} \mathrm{PGH}_{2}$ as substrate. The amount of $\mathrm{PGE}_{2}$ was quantified for $1 \mu \mathrm{M} \mathrm{PGH}_{2}$ by use of a $\mathrm{PGE}_{2} \mathrm{High}$ Sensitivity EIA Kit according to the manufacturer's protocol. The $100 \%$ value corresponds to 34 pmol PGE 2 . (C) Reversibility of mPGES-1 inhibition by garcinol and MK-886. Microsomal preparations of interleukin-1 $\beta$-stimulated A549 cells were pre-incubated with 3 $\mu \mathrm{M}$ inhibitor for $15 \mathrm{~min}$ at $4{ }^{\circ} \mathrm{C}$. An aliquot was diluted 10 -fold to obtain an inhibitor concentration of $0.3 \mu \mathrm{M}$. For comparison, microsomal preparations were pre-incubated for 15 min with vehicle (DMSO, w/o) or $0.3 \mu \mathrm{M}$ MK-886 or garcinol, and then, $20 \mu \mathrm{M} \mathrm{PGH}_{2}$ was added (no dilution). All samples were incubated for 1 min on ice, and $\mathrm{PGE}_{2}$ formation was analyzed as described by RP-HPLC. Data are given as mean + S.E., $n=2-4,{ }^{*} p<0.05$ or $* * * p<0.001$ vs. vehicle $(0.1 \%$ DMSO $)$ control, ANOVA + Tukey HSD post-hoc tests.

\section{Fig. 5. Effects of garcinol on prostanoid formation in human whole blood.}

(A) 12-HHT formation. Heparinized whole blood was pre-incubated with garcinol or vehicle (DMSO, w/o) at the indicated concentrations for $5 \mathrm{~min}$, and $\mathrm{AA}(100 \mu \mathrm{M})$ and $\mathrm{Ca}^{2+}$ ionophore $(30 \mu \mathrm{M})$ were added to induce COX-product formation. After 10 min at $37{ }^{\circ} \mathrm{C}, 12$ HHT was extracted and analyzed by RP-HPLC as described. The 100\% value corresponds to $1.0 \mu \mathrm{g} / \mathrm{ml}$ 12-HHT. Indomethacin (Indo, $20 \mu \mathrm{M}$ ) was used as control. (B, C) Heparinized human whole blood, treated with $1 \mu \mathrm{M}$ thromboxane synthase inhibitor and $50 \mu \mathrm{M}$ aspirin, was pre-incubated with the indicated concentrations of garcinol or vehicle (DMSO, w/o) for 5 min at room temperature, and then, prostanoid formation was induced by addition of $10 \mu \mathrm{g} / \mathrm{ml}$ lipopolysaccharide. After $5 \mathrm{~h}$ at $37{ }^{\circ} \mathrm{C}$, (B) $\mathrm{PGE}_{2}$ was extracted from plasma by RP-18 solid phase extraction, separated by RP-HPLC, and quantified by ELISA as described. The $100 \%$ value corresponds to $9 \mathrm{ng} / \mathrm{ml} \mathrm{PGE} 2$. (C) 6-keto $\mathrm{PGF}_{1 \alpha}$ was directly determined in blood plasma by ELISA. The $100 \%$ value corresponds to $4 \mathrm{ng} / \mathrm{ml}$ 6-keto $\mathrm{PGF}_{1 \alpha}$. MK-886 $(30 \mu \mathrm{M})$, 
indomethacin (Indo, $50 \mu \mathrm{M}$ ), celecoxib (Cele, $20 \mu \mathrm{M}$ ), or vehicle (DMSO) were used as controls. Data are given as mean $+/-$ S.E., $\mathrm{n}=3-4,{ }^{* *} p<0.01$ or $* * * p<0.001$ vs. vehicle (0.1\% DMSO) control, ANOVA + Tukey HSD post-hoc tests.

\section{Fig. 6. Inhibition of 5-lipoxygenase activity by garcinol.}

(A) Neutrophils $\left(5 \times 10^{6}\right.$ cells $\left./ \mathrm{ml}\right)$ were pre-incubated with the indicated concentrations of garcinol or vehicle (DMSO) for $15 \mathrm{~min}$. 5-LO product formation was initiated by addition of $2.5 \mu \mathrm{M} \mathrm{Ca}{ }^{2+}$-ionophore plus $20 \mu \mathrm{M}$ AA. (B) S100 of E.coli lysates expressing human recombinant 5-LO or (C) semi-purified human recombinant 5-LO were supplemented with garcinol and $1 \mathrm{mM}$ ATP, and product formation was started by addition of $2 \mathrm{mM} \mathrm{CaCl}_{2}$ and $20 \mu \mathrm{M}$ AA. The $100 \%$ values correspond to $1.8,1.3$, and $1.4 \mu \mathrm{g} / \mathrm{ml} 5$-LO products for intact cells, S100, and purified enzyme, respectively. Data are given as mean + S.E., $n=3-6,{ }^{*} p<$ $0.05,{ }^{*} p<0.01$ or $* * * p<0.001$ vs. vehicle $(0.1 \%$ DMSO) control, ANOVA + Tukey HSD post-hoc tests. 
Fig. 1

A

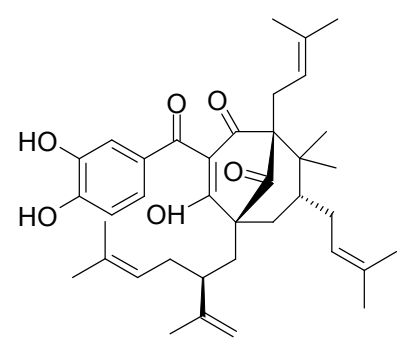

garcinol
B
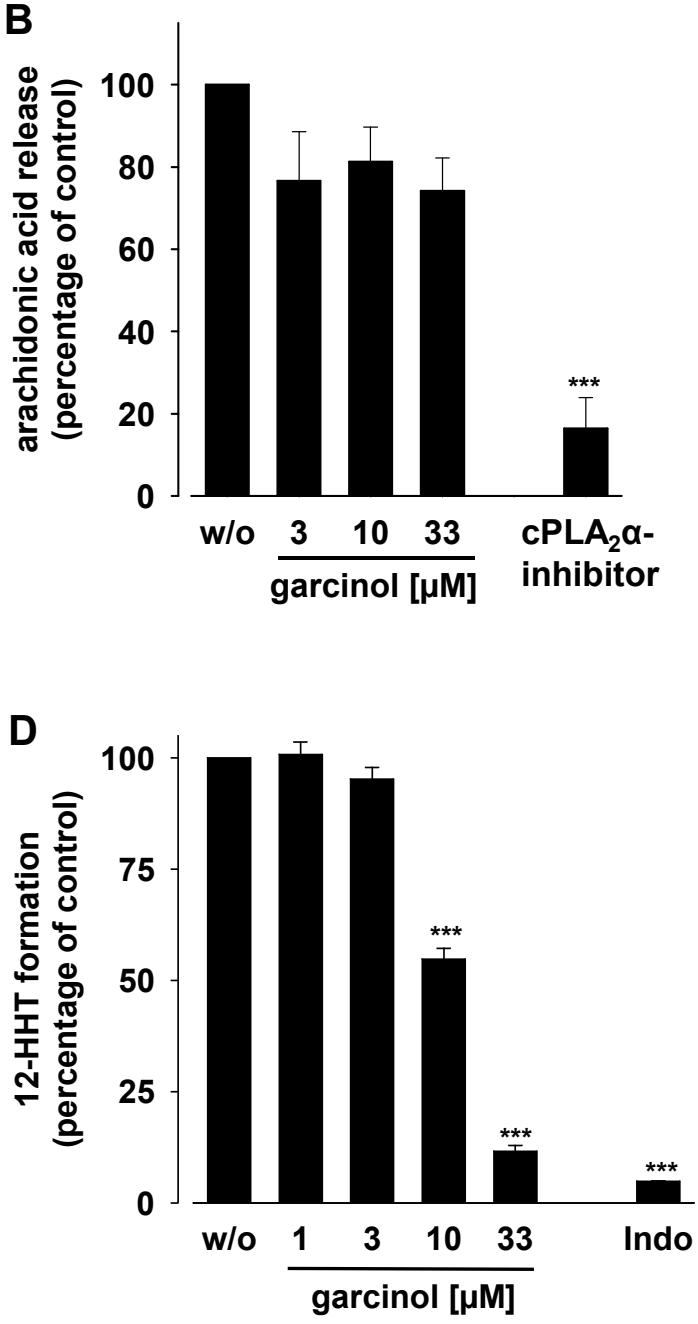

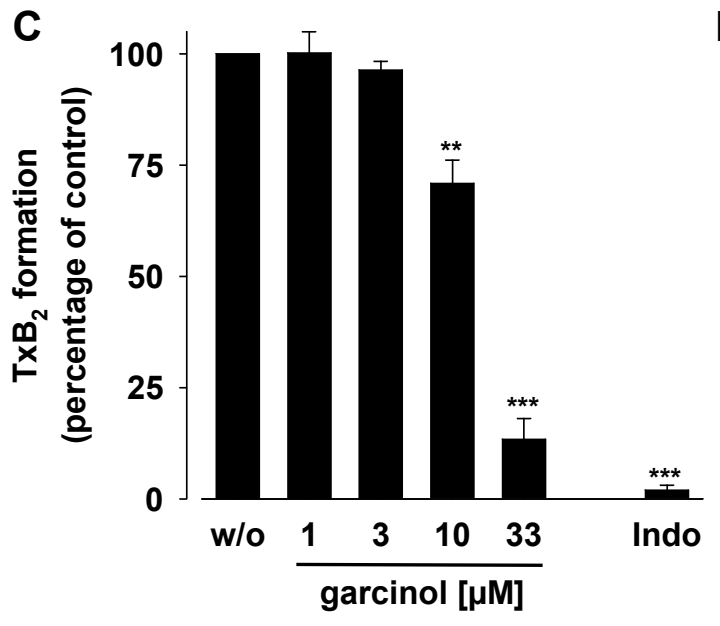


Fig. 2
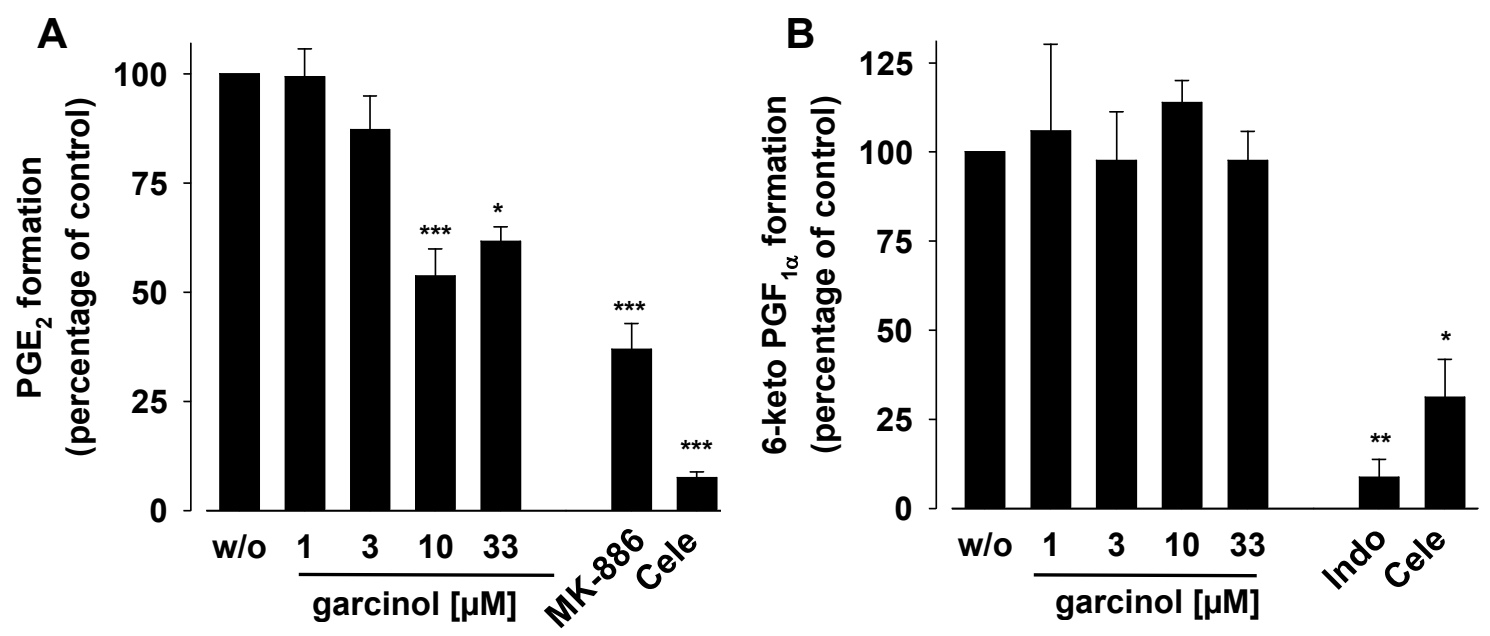
Fig. 3

A

cox-1
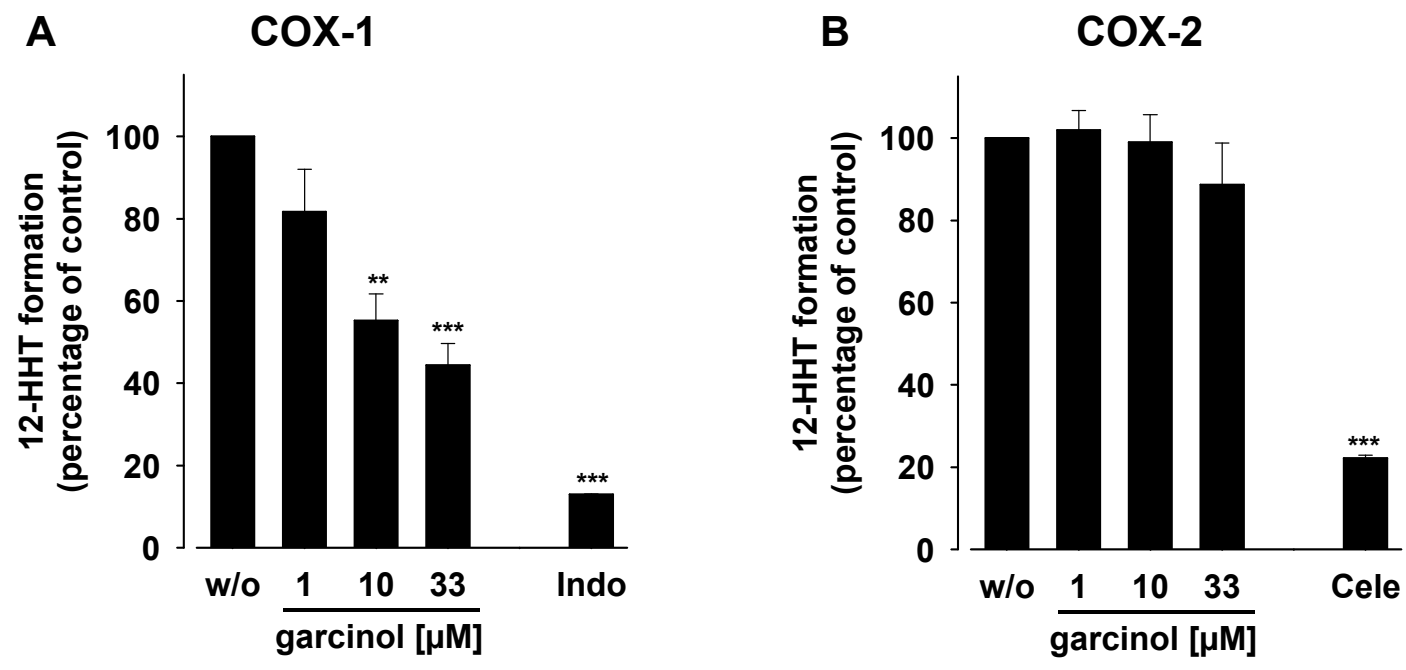
Fig. 4
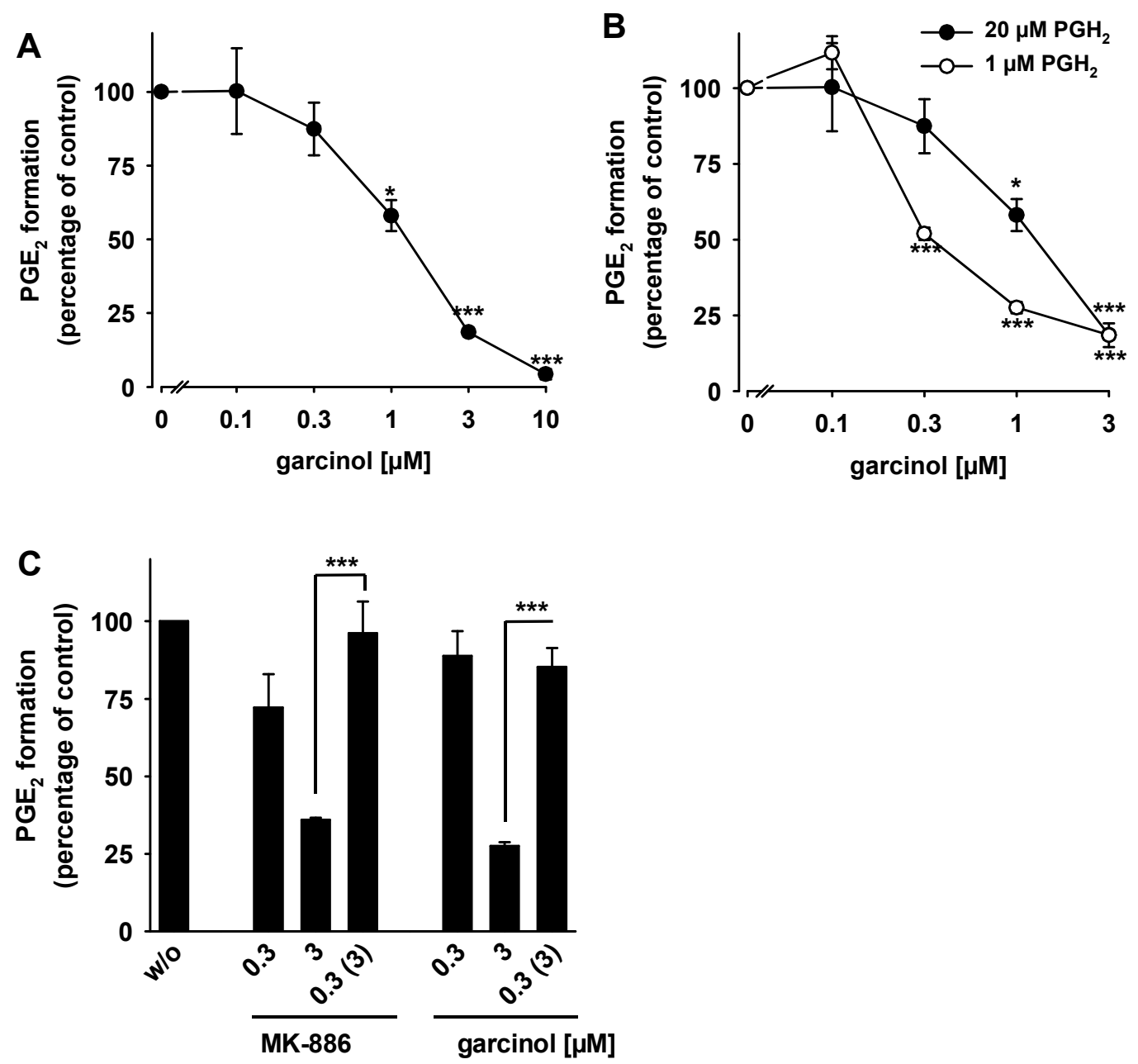
Fig. 5
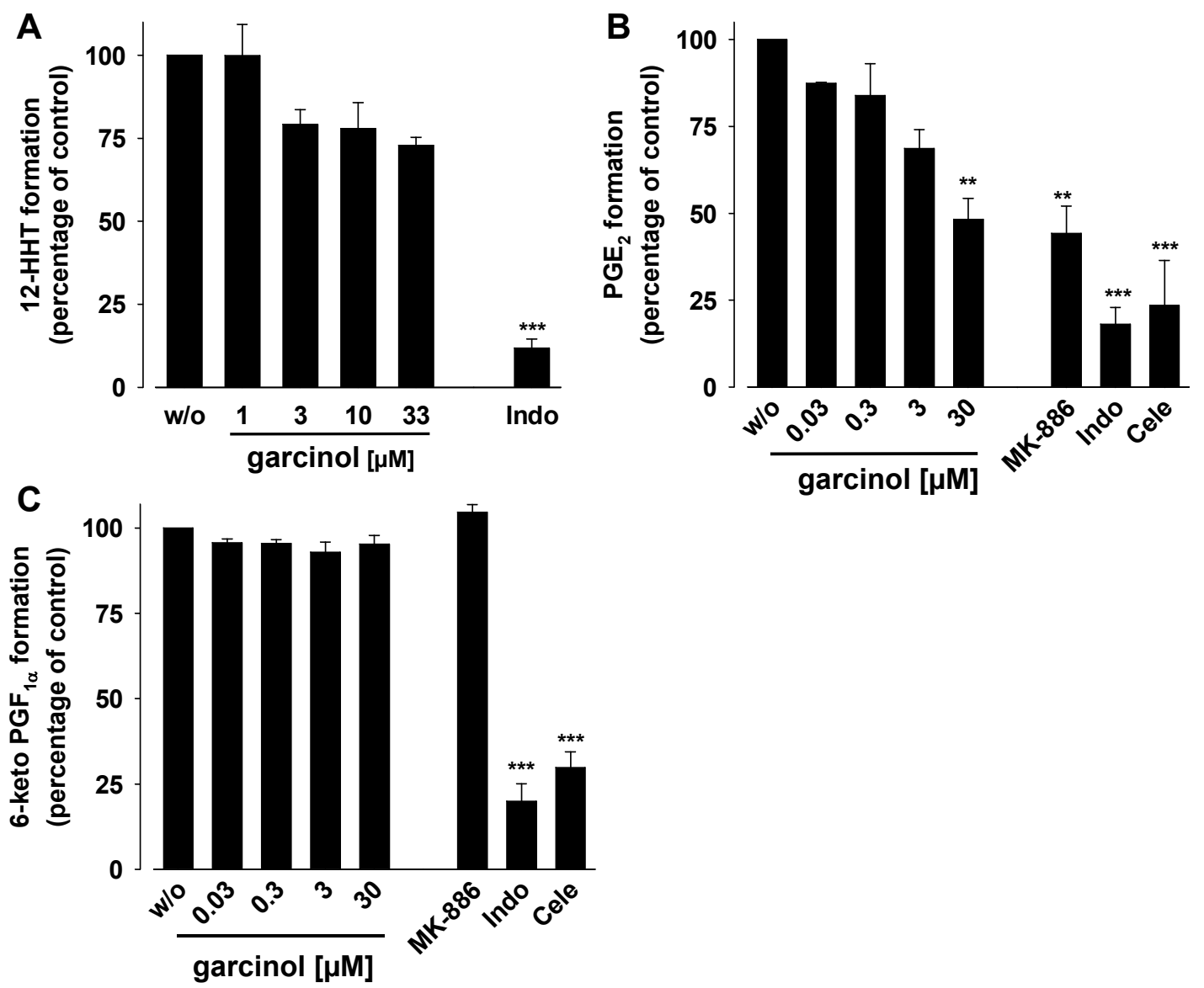
Fig. 6

A intact PMNL

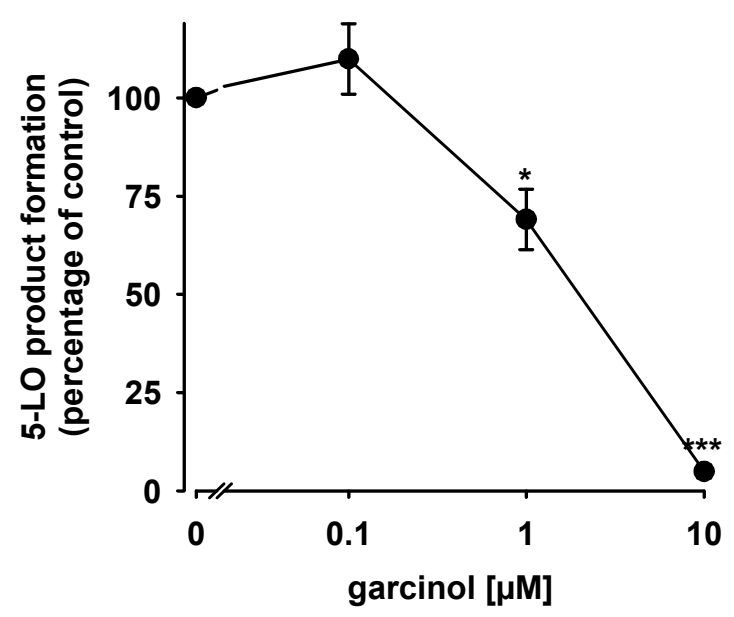

C semi-purified 5-LO

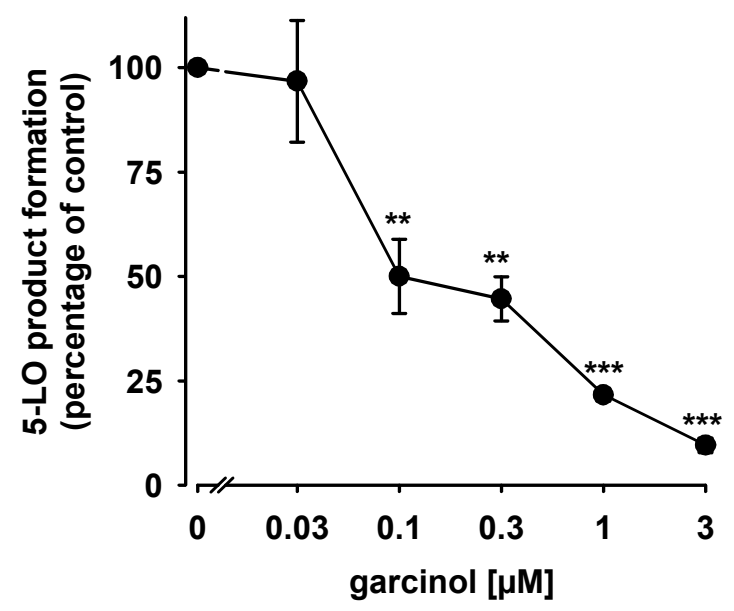

B

$\mathbf{S 1 0 0}$

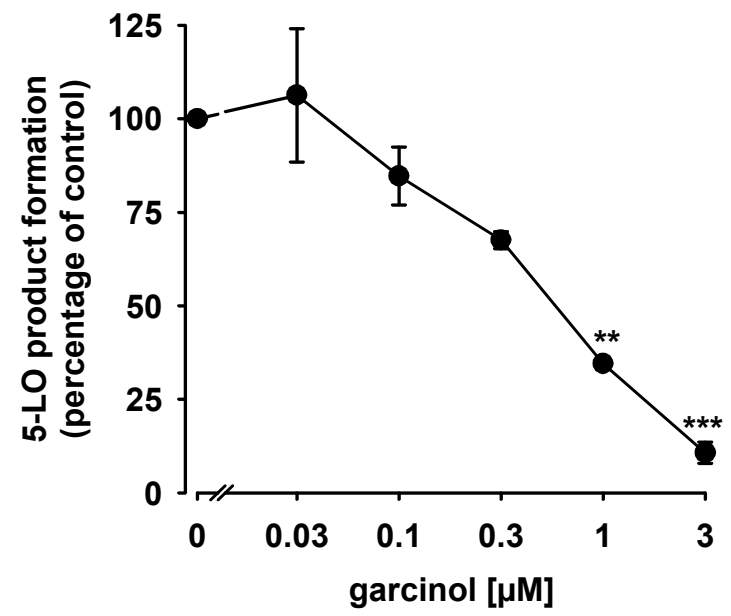




\section{graphical abstract}

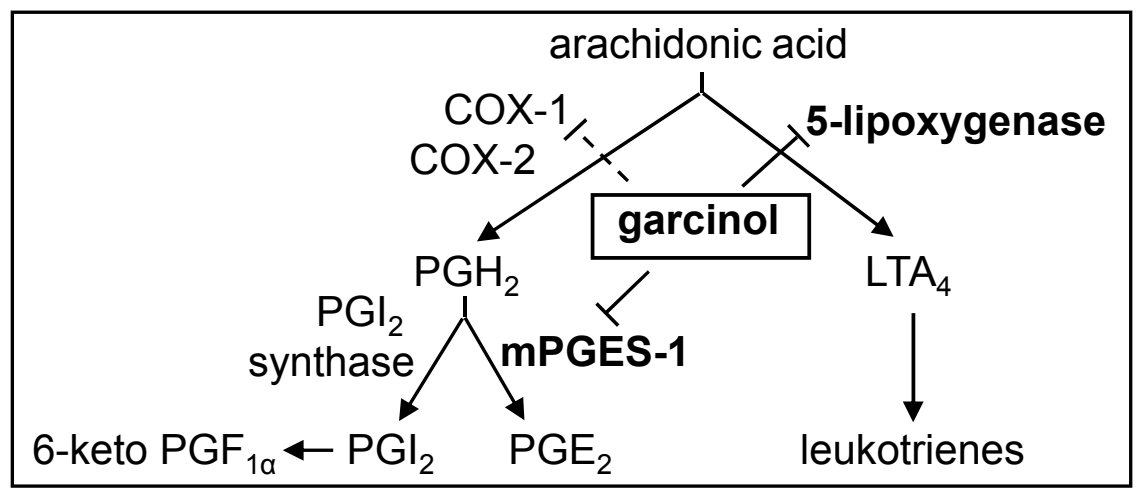

